\title{
PERAN GAYA KEPEMIMPINAN TRANSFORMASIONAL \\ DALAM MENINGKATKAN KUALITAS PELAYANAN \\ DI SEKOLAH VOKASI UNIVERSITAS DIPONEGORO
}

\author{
Luluk Fauziah'), Mashudi'2), Ida Hayu Dwimawati ${ }^{3)}$, dan Johan Bhimo Sukoco ${ }^{4)}$ \\ 1)Program Studi Administrasi Perkantoran, Sekolah Vokasi, \\ Universitas Diponegoro, Semarang \\ lulukfauz@yahoo.co.id \\ 2)Program Studi Manajemen Perusahaan, Sekolah Vokasi, \\ Universitas Diponegoro, Semarang \\ emashud_bli@yahoo.co.id \\ 3)Program Studi Administrasi Publik, Fakultas IImu Sosial \& IImu Politik, \\ Universitas Diponegoro, Semarang \\ ida2hade@gmail.com \\ 4)Program Studi Administrasi Perkantoran, Sekolah Vokasi, \\ Universitas Diponegoro, Semarang \\ johanbhimo@live.undip.ac.id
}

\begin{abstract}
Abstrak
Penyelenggaraan manajemen di perguruan tinggi tidak hanya ditentukan oleh infrastruktur, fasilitas, dan dukungan dana semata. Namun hal ini juga ditentukan keberhasilan mengelola Sumber Daya Manusia. Pemimpin merupakan penentu keberhasilan dan suksesnya tujuan ini. Kepemimpinan lebih merupakan hasil dari transformasi internal dalam diri seseorang. Gaya kepemimpinan transformasional mempunyai peran yang signifikan terhadap peningkatan kinerja karyawan.

Tujuan penelitian ini adalah untuk mengetahui peran dan kendala gaya kepemimpinan transformasional dalam meningkatkan kualitas pelayanan di Sekolah Vokasi Universitas Diponegoro. Pendekatan penelitian menggunakan metode deskriptif kualitatif. Metode pengumpulan data menggunakan wawancara, observasi, dan studi dokumen. Triangulasi data menggunakan triangulasi metode, sedangkan analisis data menggunakan analisis interaktif.

Hasil penelitian menunjukkan gaya kepemimpinan transformasional di instansi ini diarahkan sesuai dengan visi, yaitu pada tahun 2020 menjadi pusat pendidikan vokasi (terapan) yang unggul dan bertaraf internasional. Pemimpin memiliki peran signifikan dalam meningkatkan kualitas pelayanan. Pemimpin juga memainkan peranan kritis, yaitu melalui strategi peningkatan kuantitas tenaga kependidikan, peningkatan kualitas tenaga kependidikan, dan pengembangan sistem penilaian kinerja.
\end{abstract}

Kata Kunci : Peran, Gaya Kepemimpinan Transformasional, Kualitas Pelayanan.

\begin{abstract}
Organizing management in higher education is not only determined by infrastructure, facilities, and mere financial support. It is also determined by the success of managing human resources. The leader becomes the determinant of the success of this goal. Leadership is more a result of the internal transformation in an individual. Transformational leadership style has a significant role in improving employee performance.

The purpose of this study was to determine the role and constraints of the transformational leadership style in improving the quality of service in the Vocational School of Diponegoro University. The research approach employed a qualitative descriptive method. Interviews, observation, and document study were used in collecting the data. Data triangulation uses triangulation methods, while interactive analysis was applied in the data analysis.

The results showed that the transformational leadership style in this institution was directed in accordance with the vision, namely in 2020 to become a center of primary and international (applied) vocational education. Leaders have a significant role in improving service quality. Leaders also play a critical role through strategies to increase the quantity of education personnel, to improve the quality of education staffs, and to develop a performance appraisal system.
\end{abstract}

Keywords: Roles, Transformational Leadership Style, Service Quality. 


\section{PENDAHULUAN}

Perkembangan organisasi dalam sebuah perguruan tinggi dewasa ini tumbuh dan berkembang dengan sangat dinamis. Perkembangan ini memerlukan sistem manajemen yang efektif yang dapat dengan mudah menyesuaikan diri dan dapat mengakomodasikan setiap perubahan baik yang sedang dan yang telah terjadi. Sebuah organisasi sudah tidak lagi dipandang sebagai sistem tertutup, namun organisasi merupakan sistem terbuka yang harus merespon dan mengakomodasikan berbagai perubahan ekternal dengan cepat dan efisien.

Penyelenggaraan manajemen di perguruan tinggi tidak hanya ditentukan oleh infrastruktur dan fasilitas yang memadai serta dukungan dana semata, tetapi juga ditentukan dari keberhasilan dalam mengelola Sumber Daya Manusia. Manajemen Sumber Daya Manusia merupakan serangkaian tindakan mulai dari sistem seleksi, pengembangan karir, pendidikan dan latihan, dan proses penyiapan personel untuk menduduki jabatan yang lebih tinggi. Dengan demikian, masalah Sumber Daya Manusia merupakan masalah yang kompleks bagi organisasi (Sutrisno, 2013).

Manajemen kepegawaian dan Sumber Daya Manusia sangat penting bagi organisasi dalam pengelolaan, pengaturan, dan pemanfaatan pegawai sehingga dapat berfungsi secara produktif untuk tercapainya tujuan organisasi (Mangkunegara, 2011). Problematika yang ada dalam manajemen Sumber Daya Manusia, merupakan masalah yang patut mendapat perhatian setiap organisasi adalah masalah kinerja pegawai, karena kinerja pegawai sangat mempengaruhi keberhasilan suatu organisasi.

Gaya kepemimpinan yang tepat akan mampu mempengaruhi kinerja karyawan untuk mau mempelajari sistem baru yang diterapkan oleh perusahaan. Gaya kepemimpinan ini dapat diartikan sebagai sikap dan tindakan yang dilakukan pemimpin dalam menghadapi bawahan, mengatur suatu sistem operasional organisasi, menjalankan dan mengawal kebijakan dan menyelesaikan permasalahan baik internal maupun ekternal (Bass, Berry dan Houston, 1993).

Pelaksanaan layanan dan administrasi yang berlangsung di Sekolah Vokasi
Universitas Diponegoro diperankan oleh tenaga kependidikan, dimana tenaga kependidikan adalah anggota masyarakat yang mengabdikan diri dan diangkat untuk menunjang penyelenggaraan pendidikan tinggi. Tenaga kependidikan di Sekolah Vokasi Universitas Diponegoro adalah para Pegawai Negeri Sipil (PNS), ataupun Pegawai Non PNS, dan Pegawai Kontrak bagian administrasi atau struktural.

Berdasarkan penelitian dengan melihat kondisi kerja yang terjadi diduga adanya indikasi rendahnya kinerja dapat dilihat masih terjadinya keterlambatan dalam pengurusan atau penyelesaian suatu berkas dan kurang cepatnya pelayanan yang diberikan pegawai. Hal ini merupakan indikasi masih kurangnya motivasi mereka bekerja dengan adanya fenomena tersebut dimana para pegawai cenderung mengalami penurunan kinerja. Selanjutnya data dalam Rencana Strategis (Renstra) Sekolah Vokasi Universitas Diponegoro Tahun 2018-2019 jumlah tenaga kependidikan sebanyak 88 orang, jumlah ini masih belum ideal untuk melayani mahasiswa sebanyak 7.300 orang, dengan tingkat perbandingan sebesar $1: 82$. Hal ini akan berpengaruh pada kualitas layanan yang diberikan.

Dari data di atas, maka dapat dilihat bahwa jumlah tenaga kependidikan, rasionya masih belum cukup untuk melayani mahasiswa dan dosen sebagai pelanggan utama. Untuk mewujudkan kinerja organisasi yang optimal, salah satunya adalah dengan mengoptimalkan sumber manusia yang ada, menggerakkan, memberikan motivasi atau dorongan, berkoordinasi dan berkomunikasi kepada staf sehingga diharapkan tercipta suasana dan hubungan kerja yang baik.

Salah satu permasalahan pokok dalam organisasi ialah bagaimana memberi motivasi kepada bawahan untuk melakukan pekerjaan dengan baik. Pemimpin harus dapat memahami perilaku bawahan, artinya seorang pemimpin dalam tugas keseluruhan hendaknya dapat memperhatikan, mengamati perilaku para bawahan, dengan memahami perilaku mereka akan lebih memudahkan tugasnya memberikan motivasi. 


\section{TINJAUAN PUSTAKA}

\section{Gaya Kepemimpinan}

Gaya kepemimpinan ialah pola perilaku dari para pemimpin yang dilakukan pemimpin selama melaksanakan pekerjaan dengan dan melalui bantuan orang lain (Ali, 2013). Kepemimpinan demokratik (employeeoriented) dan autokratik (task-oriented supervisor), (Afolabi, 2008). Lebih lanjut, kepemimpinan autokratik ini dipandang sebagai gaya kepemimpinan yang didasari oleh kekuatan posisi, tanggung jawab yang biasanya ditanggung oleh pimpinan, serta pemberian wewenang yang berpusat pada pemimpin itu sendiri.

Di sisi lain, gaya kepemimpinan demokratik lebih dikaitkan dengan kekuatan personal, dimana hal ini berarti kekuatan wewenang pimpinan tidak mutlak. Pimpinan dapat membuat sebuah kebijakan yang pembuatannya melibatkan bawahan. Uniknya, bawahan diberikan kesempatan untuk ikut serta dalam proses pengambilan keputusan serta pemecahan masalah dalam sebuah organisasi.

Gaya kepemimpinan ini meliputi bagaimana seseorang memobilisasi, mempengaruhi, memotivasi, menginspirasi, serta memberikan peluang kepada seluruh anggota organisasi untuk mencapai potensi maksimal. Untuk mewujudkan hal ini secara efektif, maka seorang pemimpin perlu belajar dan segera mempersiapkan pilihan gaya kepemimpinan mana yang akan diambil dan keterampilan apa yang akan dipergunakan dalam berbagai situasi tertentu.

Pimpinan yang tidak memiliki gaya kepemimpinan tidak akan sukses dalam mendorong anggota organisasi dalam mencapai potensinya. Dapat dikatakan ia tidak akan berhasil memimpin organisasi. Adapun budaya organisasi dan ekspektasinya terhadap anggota yang dipimpinnya mengharuskan seorang pemimpin mengadopsi sebuah gaya kepemimpinan. Gaya kepemimpinan itu sendiri merupakan cara seorang pimpinan untuk bertindak. .

Gaya kepemimpinan ini dapat mencakup (Kumaran, 2012):

1. Faktor fisik, yang meliputi bahasa tubuh (body language), kontak mata (eye contact), nada bicara atau suara (voice), dan kata-kata yang digunakan.
2. Faktor karakteristik yang diperlihatkan dari sifat kerendahan hati, kecerdasan, atau intelektualitas.

Gaya kepemimpinan tergantung pada nilai individu, latar belakang budaya, keyakinan, latar belakang organisasi, serta kepribadian. Maka, hal ini tidak mudah dalam merumuskan gaya kepemimpinan mana yang dirasa paling baik yang dapat diterapkan untuk semua organisasi mengingat gaya kepemimpinan snagat bergantung pada nilai-nilai tersebut.

Terkait dengan hal tersebut beberapa ahli merumuskan berbagai gaya kepemimpinan, diantaranya menurut Northouse, P.G dalam Reeder yang memuat sepuluh gaya kepemimpinan yaitu: autocratic, bureauctaric, democratic, laissez-faire, charismatic, transformational, transactional, strategic, delegative, dan authoritarian (Reeder, 2012). Sedangkan menurut Siagian dalam Sugiyanti (2012), menyebutkan terdapat 5 (lima) gaya kepemimpinan yaitu: otokratik, paternalistik, kharismatik, demokratik, dan laissez-faire.

\section{Kepemimpinan Transformasional}

Kepemimpinan didefinisikan sebagai kesanggupan dalam mempengaruhi perilaku orang lain dalam arah tertentu (Hughes, Ginnett, dan Curphy, 1993). Lebih lanjut, kepemimpinan juga dapat diartikan suatu usaha dalam mempengaruhi orang antar perseorangan (interpersonal), melalui proses komunikasi untuk mencapai tujuan tertentu (Gibson, Ivancevich dan Donnely, 1987). Bass (Harsiwi, 2003), menyatakan bahwa kepemimpinan yang baik idealnya dapat menjalankan salah satu atau kombinasi dari 4 (empat) cara ini, yaitu :

1. Memberi kesadaran misi, membangkitkan kebanggaan, serta menumbuhkan sikap menghormati dan kepercayaan pada bawahannya (Idealized Influence-kharisma),

2. Menumbuhkan ekspektasi yang tinggi melalui pemanfaatan simbol untuk memfokuskan usaha dan mengkomunikasikan tujuan dengan cara yang sederhana (Inspirational Motivation),

3. Meningkatkan intelegensia, rasionalitas, dan pemecahan masalah secara seksama (Intellectual Stimulation),

4. Memberikan perhatian, membina, 
membimbing, dan melatih setiap orang secara khusus dan pribadi (Individualized Consideration).

Peran pemimpin sangat dibutuhkan dalam menggerakan organisasi secara optimal, dalam menjalankan perannya, pemimpin harus mempunyai ketrampilan memimpin dan gaya kepemimpinan yang sesuai dengan tuntutan zaman. Gaya kepemimpinan dari seorang pemimpin, pada dasarnya dapat diterangkan melalui tiga aliran teori (Hersey dan Blanchard dalam Mustopadidjaja, 2005), yaitu :

1. Teori Genetis (Keturunan). Teori ini merumuskan bahwa "Leader are born and nor made" (pemimpin itu dilahirkan, bukannya dibuat). Penganut teori ini menyatakan bahwa pemimpin dilahirkan oleh bakat. Jadi, dalam kondisi apapun, seseorang akan tetap menjadi pemimpin dan akan muncul sebagai pemimpin sesuai bakat lahiriah.

2. Teori sosial. Teori ini merumuskan bahwa "Leader are made and not born" (pemimpin itu dibuat atau dididik bukannya kodrati). Teori ini merupakan kebalikan dari Teori Genetis. Seseorang akan dapat menjadi pemimpin jika diberikan pengalaman serta pendidikan yang memadai.

3. Teori Ekologis. Teori ini menyebutkan bahwa seseorang akan menjadi pemimpin yang baik jika ia memiliki sebuah bakat kepemimpinan. Bakat ini dikembangkan melalui pendidikan dan pengalaman. Jadi, teori ini lebih menggabungkan Teori Genetis dan Teori Sosial.

Konsep kepemimpinan transformasional untuk pertama kali dinyatakan oleh James Mc Gregor Bums. Berkaitan dengan kepemimpinan transformasional, Bernard Bass (Stone et. Al, 2004), menuliskan bahwa:

"Transformational leaders transform the personal values of followers to support the vision and goals of the organization by fostering an environment where relationships can be formed and by establishing a climate of trust in which visions can be shared".

\section{Pengertian Pelayanan}

Menurut Tjiptono (2014) istilah service dalam Bahasa Indonesia setidaknya memiliki 3 (tiga) kata yakni jasa, layanan, dan servis. Sebagai jasa, layanan umumnya mencerminkan produk tidak berwujud (intangible) atau sektor industri spesifik seperti pendidikan, kesehatan, telekomunikasi, transportasi, asuransi, perbankan, perhotelan dan seterusnya. Pada hakikatnya layanan sebagai jasa bersifat intangible (tidak teraba), yang merupakan pemenuhan kebutuhan dan tidak harus terikat pada penjualan produk atau pelayanan lain.

Pelayanan dapat diartikan sebagai segala sesuatu yang dilakukan oleh pihak baik secara individu maupun kelompok kepada pihak lain, contohnya pelayanan pelanggan yang mencakup aktivitas menjawab pelayanan pelanggan, penanganan komplain, serta memproses pesanan. Selain itu, proses mengintalasi produk dan mereparasi produk merupakan bentuk pelayanan.

Menurut Kotler (Lukman, 2000), pelayanan merupakan setiap kegiatan yang dilakukan dengan menguntungkan kumpulan ataupun kesatuan, serta menawarkan kepuasan. Hal ini dengan catatan, meskipun tidak terkait suatu produk secara fisik. Lebih lanjut, pelayanan merupakan kegiatan yang terjadi dalam sebuah interaksi langsung antara seseorang dengan orang lain ataupun dengan mesin sera fisik, serta menyediakan kepuasan bagi pelanggan. Pelayanan juga dapat diartikan sebagai, hal, secara, atau hasil pekerjan melayani (Sinambela, 2006).

Moenir (1997) menyatakan bahwa pelayanan sebagai proses pemenuhan kebutuhan melalui kegiatan atau aktivitas organg lain secara langsung. Konsep ini sangat aktual dalam berbagai aspek kelembagaan. Kondisi ini bukan hanya di organisasi bisnis, melainkan pada aspek organisasi pemerintahan. Hal tersebut disebabkan perkembangan ilmu pengetahuan dan teknologi (iptek) yang semakin berkembang.

Berdasarkan beberapa pendapat diatas dapat disimpulkan bahwa pelayanan adalah kegiatan yang bertujuan untuk memenuhi kebutuhan atau memberikan kepuasan kepada pelanggan melalui penawaran jasa (intangible) atau produk oleh penyedia layanan. Perkembangan selanjutnya menurut 
Gilmore dalam Tjiptono (2014) layanan dapat dibedakan menjadi service sebagai aktivitas dan service sebagai konsep.

Pelayanan publik mencakup kepuasan pelanggan, dalam hal ini jasa akan dipandang sebagai fungsi tambahan dari sebuah produk fisik maupun non fisik. Pemberian pelayanan akan memberikan keunggulan kompetitif, seperti keramahan, serta kesigapan pegawai dalam menangani keluhan customer. Layanan ini dapat berwujud stuktur organisasi (yang berkecipung dalam bidang jasa, baik bisnis maupun nirlaba), produk inti (merupakan perluasan produk atau aktivitas tambahan yang dirancang untuk memfasilitasi penyampaian produk inti), product support (dimana setiap aktivitas berorientasi pada pelanggan yang berlangsung setelah produk inti disampakan kepada customer), serta tindakan dalam membantu memberikan saran kepada pelanggan. Dengan demikian, pada hakikatnya setiap bisnis ialah bisnis jasa atau layanan.

Sebuah organisasi dalam lingkup internal mengenal istilah pelanggan internal. Hal ini berarti bahwa setiap departemen ataupun individu berperan sebagai penyedia maupun penerima layanan departemen atau individu lainnya. Adapun di sisi lain, kualitas pelayanan yang diberikan kepada kualitas relasi serta kerjasama pelanggan internal. Berlandaskan hal ini, maka kepuasan dan loyalitas pelanggan eksternal akan dapat terwujud secara efektif jika kepuasan dan loyalitas pelanggan internal dapat tercipta dengan baik.

\section{Kualitas Pelayanan}

Dalam rangka memberikan pelayanan secara maksimal dalam suatu institusi pendidikan, maka perlu diadakan pembinaan kelembagaan. Langkah ini sangat penting mengingat hal ini untuk memperbaiki pelayanan itu sendiri. Pembinaan ini memerlukan kontiunitas. Tingkat kepuasan yang diterima oleh pengguna layanan tentu akan terus berubah seiring dengan semakin baiknya tingkat pendidikan.

Kualitas merupakan sebuah kondisi dinamis yang memiliki pengaruh terhadap jasa, produk, manusia, proses dan lingkungan yang memenuhi ataupun melebihi harapan (Tjiptono, 2012). Terkait hal ini, maka kualitas pelayanan diartikan sebagai pemenuhan kebutuhan serta keinginan konsumen. Kualitas pelayanan (service quality) akan dapat diketahui dari cara atau perolehan dengan pelayanan yang sesungguhnya mereka harapkan. Apabila jasa yang diterima ataupun dirasakan sesuai dengan yang diharapkan, maka kualitas pelayanan dikatakan atau dipresepsikan baik. Di sisi lain, jika jasa yang diterima lebih rendah dari pada yang diharapkan, maka kualitas pelayanan dipersepsikan buruk/tidak sesuai dengan harapan konsumen.

Lebih lanjut, Kotler (2004) menuliskan kualitas pelayanan merupakan bentuk persepsi dari konsumen terhadap tingkat pelayanan yang mereka diterima (perceived service) dengan tingkat pelayanan yang mereka harapkan (expected sevice). Apabila pelayanan yang diterima atau yang dirasakan tersebut sudah sesuai dengan yang diharapkan, maka dapat dikatakan kualitas pelayanan dipersepsikan baik dan memuaskan. Adapun kepuasan yang telah dibentuk ini dapat mendorong konsumen melakukan pembelian ulang dan nantinya menjadi pelanggan yang memiliki loyalitas.

Menurut Philip Kotler (Buchari Alma, 2007) menuliskan 5 (lima) determinan kualitas pelayanan, yang disingkat dengan TERRA yaitu : 1. Tangible (berwujud), yaitu berupa penampilan fasilitas fisik, peralatan dan berbagai materi komunikasi yang baik, menarik dan terawat lancer; 2. Emphaty, yaitu kesediaan karyawan dan pengusaha untuk lebih peduli memberikan perhatian secara probadi kepada pelanggan; 3. Responsiveness (cepat tanggap) yaitu kemauan dari karyawan dan pengusaha untuk membantu prelanggan dan memberikan jasa dengan cepat serta mendengar dan mengatasi keluhan dari konsumen; 4. Reliability (keandalan) yaitu kemampuan untuk memberikan jasa sesuai dengan yang dijanjikan, terpercaya dan akurat dan konsisten; 5. Assurance (kepastian) yaitu berupa kemampuan karyawan untuk menimbulkan keyakinan dan kepercayaan terhadap janji yang telah dikemukakan kepada konsumen.

\section{METODE PENELITIAN}

Penelitian ini merupakan penelitian deskriptif kualitatif. Teknik pengumpulan data menggunakan wawancara, observasi, dan 
dokumentasi.

menggunakan

Triangulasi triangulasi

sedangkan analisis interaktif digunakan dalam analisis data.

Penelitan ini menggunakan teknik purposive sampling. Hal ini bertujuan untuk menjamin heterogenitas dari sampel tersebut dengan fokusan terhadap informan karyawan tenaga kependidikan. Unit analisis dalam penelitian ini ialah manusia. Keempat komponen kepemimpinan transformasional menurut Bass (Harsiwi, 2003), akan dianalisis dalam penelitian ini, meliputi : Idealized Influence-kharisma, Inspirational Motivation, Intellectual Stimulation, Individualized Consideration.

\section{HASIL DAN PEMBAHASAN}

Hasil penelitian menunjukkan jumlah tenaga kependidikan di Sekolah Vokasi Universitas Diponegoro masih belum mencukupi jika dibandingkan dengan kuantitas mahasiswa. Jumlah tenaga kependidikan sejumlah 88 orang, sedangkan jumlah mahasiswa berjumlah 7.300 orang. Maka rasio antara tenaga kependidikan dengan jumlah mahasiswa ialah $1: 82$.

Tenaga kependidikan bergelar S2 sejumlah 9 orang, S1 sejumlah 20 orang, D3 sejumlah 9 orang, SMA/K sejumlah 36 orang, dan SD sejumlah 5 orang. Berikut ini dapat dilihat dalam Tabel 1 :

Tabel 1. Jumlah Tenaga Kependidikan di Sekolah Vokasi Universitas Diponegoro

\begin{tabular}{|c|c|c|c|c|c|c|c|}
\hline \multirow[t]{2}{*}{ No } & \multirow{2}{*}{$\begin{array}{l}\text { Jenis Tenaga } \\
\text { Kependidikan }\end{array}$} & \multicolumn{6}{|c|}{$\begin{array}{c}\text { Jumlah Tenaga Kependidikan dengan } \\
\text { Pendidikan Terakhir }\end{array}$} \\
\hline & & S2 & S1 & D3 & SMA/K & SMP & SD \\
\hline 1 & Pustakawan & 3 & 12 & 0 & 0 & 0 & 0 \\
\hline 2 & $\begin{array}{l}\text { Laboran/ Teknisi/ } \\
\text { Analis/ Operator/ } \\
\text { Programer }\end{array}$ & 1 & 8 & 2 & 2 & 0 & 1 \\
\hline 3 & Administrasi & 5 & 10 & 6 & 16 & 1 & 0 \\
\hline 4 & Lainnya & 0 & 0 & 1 & 18 & 8 & 4 \\
\hline & Total & 9 & 20 & 9 & 36 & 9 & 5 \\
\hline
\end{tabular}

Sumber : data primer dan sekunder.

Beranjak dari Tabel 1 dapat disimpulkan bahwa tenaga kependidikan di Sekolah Vokasi Universitas Diponegoro masih tergolong kurang secara kuantitas. Menindaklanjuti hal ini, maka jajaran pimpinan Sekolah Vokasi Universitas Diponegoro mengambil langkah transformasi dengan melakukan penambahan tenaga kependidikan. Penambahan tenaga kependidikan ini dilakukan untuk mengganti jumlah tenaga kependidikan yang memasuki masa pensiun.

Penambahan tenaga kependidikan ini dilakukan melalui berbagai formasi, antara lain : Pegawai Negeri Sipil (PNS), Pegawai Undip Non PNS (PU Non PNS), dan Pegawai Kontrak. Perencanaan ini merupakan strategi transformational dari pimpinan Universitas Diponegoro yang dikuatkan oleh jajaran pimpinan di Sekolah Vokasi.

Adapun perencanaan Sumber Daya
Manusia yang dilakukan ini dilandasi oleh formasi yang dibutuhkan, jadwal, jumlah, dan kualifikasi, dengan tujuan agar mendapatkan tenaga kependidikan yang sesuai dengan yang diharapkan. Hal ini merupakan bentuk kepemimpinan transformasional dimana berusaha memecahkan problem mendasar terkait Sumber Daya Manusia.

Beberapa strategi lainnya yang dilakukan pimpinan Sekolah Vokasi Universitas Diponegoro dalam meningkatkan kualitas ini, antara lain : peningkatan kuantitas tenaga kependidikan, peningkatan kualitas tenaga kependidikan, dan pengembangan sistem penilaian kinerja / remunerasi. 


\section{Peningkatan Kependidikan}

Kuantitas

Pertama, dalam rangka peningkatan kualitas pelayanan di Sekolah Vokasi Universitas Diponegoro, maka pimpinan melakukan strategi peningkatan jumlah atau kuantitas tenaga kependidikan melalui rekruitmen Pegawai Negeri Sipil (PNS), Pegawai Undip Non PNS (PU Non PNS), dan Pegawai Kontrak. Jadi, pimpinan mengajukan usulan pembukaan rekruitmen tenaga kependidikan disesuaikan dengan kebutuhan Sekolah Vokasi. Hal ini dirasa penting untuk memenuhi rasio ideal antara tenaga kependidikan dengan mahasiswa. Dengan demikian, maka kualitas pelayanan diharapkan akan dapat tercapai secara optimal.

Kondisi ini seperti yang dikatakan $\mathrm{A} 03$ selaku pegawai di Sekolah Vokasi Universitas Diponegoro, sebagai berikut : "Pimpinan juga sangat fokus pada kecukupan tenaga kependidikan di kampus ini. Hal ini menjadi prioritas dalam pengembangan SDM. Rasio dosen dengan mahasiswa, dan rasio tenaga kependidikan sangat diperhatikan."

\section{Peningkatan Kualitas Kependidikan}

Tenaga

Kedua, dalam rangka melakukan peningkatan kualitas pelayanan, maka pimpinan Sekolah Vokasi Universitas Diponegoro melakukan peningkatan kualifikasi pendidikan (baik bergelar maupun non gelar) yang ditujukan bagi tenaga kependidikan. Hal ini bertujuan agar kompetensi tenaga kependidikan di Sekolah Vokasi Universitas Diponegoro semakin meningkat. Pimpinan melakukan terobosan dengan memberikan beasiswa untuk pendidikan lanjut (studi lanjut) bagi tenaga kependidikan. Selain itu, pimpinan juga memberikan peluang peningkatan kompetensi bagi tenaga kependidikan melalui pendidikan dan pelatihan (diklat), workshop, dan lain sebagainya.

Beberapa Bimbingan Teknis (Bimtek) juga mengikutsertakan tenaga kependidikan dengan tujuan peningkatan pelayanan. Beberapa Bimtek ini antara lain pelatihan webmaster, Bimtek Sistem Penjaminan Mutu Akademik Universitas Diponegoro, dan lain sebagainya. Bimtek-bimtek ini penting dalam meningkatkan kompetensi tenaga kependidikan, sehingga pelayanan akan dapat ditingkatkan.

Jika dilihat dari sebaran kualifikasi tenaga kependidikan, maka sejumlah 10,22 \% tenaga kependidikan bergelar S2, 22,7 \% tenaga kependidikan bergelar S1, dan 10,22 \% bergelar D3. Hal ini tentu dirasa kurang memenuhi kaidah manajemen Sumber Daya Manusia, mengingat kuantitas tenaga kependidikan yang menempuh perguruan tinggi hanya sedikit dibandingkan lulusan SMA ke bawah.

Pengembangan Sumber Daya Manusia sangat dikedepankan pimpinan Sekolah Vokasi Universitas Diponegoro. Hal ini seperti yang dikemukakan $\mathrm{A} 02$, selaku tenaga pengajar, sebagai berikut : "Pimpinan di kampus ini sangat mengedepankan kualitas SDM. Pegawai, baik itu dosen maupun tenaga kependidikan diberikan kesempatan untuk diklat, workshop, atau bahkan studi lanjut."

Beranjak dari hal ini, maka pimpinan Sekolah Vokasi Universitas Diponegoro mendorong tenaga kependidikan untuk melanjutkan pendidikan. Skema studi lanjut bagi tenaga kependidikan disesuaikan dengan kompetensi yang hendak dicapat. Selain itu, Universitas Diponegoro juga menyediakan beasiswa bagi tenaga kependidikan untuk melanjutkan studi. Dengan demikian, diharapkan kualitas pelayanan akan dapat dicapai. Hal ini membuktikan bahwa pimpinan Sekolah Vokasi Universitas Diponegoro telah menerapkan gaya kepemimpinan transformasional dengan mendukung kapasitas Sumber Daya Manusia.

\section{Pengembangan Sistem Penilaian Kinerja / Remunerasi}

Ketiga, dalam rangka melakukan peningkatan kualitas pelayanan di Sekolah Vokasi Universitas Diponegoro, maka pimpinan melakukan pengembangan sistem penilaian kinerja dan remunerasi. Pimpinan Sekolah Vokasi Universitas Diponegoro menerapkan gaya kepemimpinan transformasitonal dengan mengikuti peraturan terkait remunerasi. Hal ini seperti tertuang dalam Peraturan Rektor Universitas Diponegoro Nomor 11 Tahun 2017 tentang Pedoman Perhitungan Intensif Kinerja Wajib, Intesif Kelebihan Kinerja Pegawai Tetap Universitas Diponegoro dan Beban Kerja Dosen. 
Peraturan tersebut merupakan legalitas pengganti peraturan sebelumnya. Melalui peraturan rektor ini, maka Peraturan Rektor Nomor 8 Tahun 2015 tentang Pedoman Penetapan Kinerja, Evaluasi Kinerja, dan Penilaian Prestasi Kerja bagi Jabatan Dosen, Tugas Tambahan, dan Tenaga Kependidikan Dalam Rangka Pelaksanaan Remunerasi di Lingkungan Universitas Diponegoro, dicabut. Adapun peraturan rektor ini mulai diberlakukan sejak tanggal 3 Januari 2017.

Pimpinan Sekolah Vokasi Universitas Diponegoro menerapkan peraturan rektor ini dengan harapan kinerja pegawai akan meingkat. Hal ini utamanya dalam peningkatan kualitas pelayanan. Hal ini penting, karena kinerja pegawai (dalam hal ini tenaga kependidikan) bukan dinilai dari prinsip 'like - dislike' atau kedekatan dengan pimpinan, melainkan lebih dinilai berdasarkan output atau pencapaian kinerja dari tenaga kependidikan yang bersangkutan.

Penerapan sistem remunerasi bagi tenaga kependidikan ini dilakukan melalui sistem online yang dapat diakses di : skp.apps.undip.ac.id. Aplikasi ini dapat diakses dimanapun, sehingga akan memudahkan bagi tenaga kependidikan untuk mengaksesnya. Pengukuran kinerja juga semakin terukur dengan baik dengan menggunakan sistem remunerasi ini.

Gambaran penerapan sistem remunerasi ini, telah diuraikan dalam Bab II Pasal 4, 5, dan 6. Pada Pasal 4, disebutkan bahwa Intensif Kinerja Wajib (IKW) tenaga kependidikan dihitung berdasarkan capaian kinerja tenaga kependidikan. Adapun capaian kinerja tenaga kependidikan ini dihitung berdasarkan capaian jam kerja, kehadiran, dan ataupun capaian keluaran.

Pada Pasal 5 ayat 1 telah disebutkan bahwa kekurangan dalam pencapaian jam kerja kehadiran ddan atau capaian luaran tenaga kependidikan dari target kinerja wajib dapat dipenuhi dengan konversi jam kerja penugasan kegiatan pada tenaga kependidikan. Lebih lanjut, ayat 2, menuliskan bahwa konversi jam kerja penugasan kegiatan pada tenaga kependidikan berpedoman pada ketentuan, antara lain :

Pertama, dikonversikan ke dalam 1 jam kerja untuk setiap nilai sebesar Rp 50.000,(lima puluh ribu rupiah) berdasarkan tarif yang telah diatur dalam Standar Biaya Universitas
Diponegoro (SBU) atau biaya standar lainnya yang telah ditetapkan oleh dekan atau pimpinan lembaga. Kedua, konversi jam kerja dilaksanakan berdasarkan urutan waktu penugasan kegiatan tenaga kependidikan.

Remunerasi ini meningkatkan kinerja pegawai secara signifikan. Hal ini seperti yang diungkapkan A01, selaku tenaga kependidikan Sekolah Vokasi Universitas Diponegoro, sebagai berikut : "Adanya remunerasi ini, menambah semangat kami untuk bekerja lebih baik lagi. Kami senang kinerja kami berbanding lurus dengan intensif yang kami terima. Kami senang pimpinan sangat memprioritaskan hal ini,"

Pada Pasal 6, disebutkan bahwa perhitungan nilai capaian kinerja tenaga kependidikan berdasarkan dokumen Sasaran Kinerja Pegawai (SKP) tenaga kependidikan yang disusun pada setiap akhir semester. Adapun pedoman pembayaran dan perhitungan Intensif Kinerja Wajib (IKW) tenaga kependidikan ini mengacu pada ketentuan dalam Peraturan Rektor tentang Penghasilan Lain PNS dan Non PNS. Lebih lanjut, format dan petunjuk pengisian Sasaran Kinerja Pegawai (SKP) tenaga kependidikan ini diatur dalam Keputusan Rektor.

$\mathrm{Di}$ sisi lain, terkait perhitungan Intensif Kelebihan Kinerja (IKK) bagi tenaga kependidikan telah diatur dalam Pasal 15, 16, dan 17. Pada Pasal 15, misalnya, telah menyebut bahwa perhitungan Intensif Kelebihan Kinerja (IKK) tenaga kependidikan disusun dan disahkan oleh Dekan, pimpinan lembaga, atau pejabat setingkat enselon II. Sasaran Kinerja Pegawai (SKP) tenaga kependidikan ini berisi data atau informasi atas kegiatan yang sekurang-kurangnya meliputi : target dan realisasi capaian kerja atau keluaran setiap pegawai, capaian jam kerja pegawai dalam satu semester, dan penilaian kinerja pegawai.

Pada Pasal 16, disebutkan bahwa tenaga kependidikan wajib memiliki pengesahan Sasaran Kinerja Pegawai (SKP) setiap semester dari pejabat yang berwenang sebagai dasar pembayaran Intensif Kelebihan Kinerja (IKK). Kemudian, tenaga kependidikan akan mendapatkan Intensif Kelebihan Kinerja (IKK) ini sebesar 100\% dari tarif dalam Standar Biaya Universitas Diponegoro (SBU) atau tarif yang ditetapkan oleh Dekan dengan persyaratan yang meliputi: memenuhi capaian realisasi 
keluaran dan atau capaian jam kerja untuk pembayaran Intensif Kinerja Wajib (IKW); dan perhitungan capaian realisasi keluaran dan/atau capaian jam kerja hanya untuk pelaksanaan tugas dalam penugasan tenaga kependidikan.

Lebih lanjut, pada Pasal 17, disebutkan bahwa persyaratan pembayaran Intensif Kelebihan Kinerja (IKK) sebesar 100\% dikecualikan untuk kegiatan yang meliputi: a) kegiatan kerjasama yang dikelola pengeluarannya melalui badan pengelola kerjasama atau badan pengelola satuan usaha, b) kegiatan tenaga kependidikan di luar dimana tenaga kependidikan ditugaskan; dan/atau, c) kegiatan tenaga kependidikan dalam melaksanakan tugas di luar tugas dan fungsinya.

Pada pasal ini juga dijelaskan bahwa pembayaran Intensif Kelebihan Kinerja (IKK) kepada tenaga kependidikan sebesar $100 \%$ untuk kegiatan dapat dilaksanakan sepanjang telah memenuhi capaian minimal keluaran atau jam kerja pada dimana tenaga kependidikan ditugaskan. Kemudian, pembayaran Intensif Kelebihan Kinerja (IKK) kepada tenaga kependidikan dibebankan pada anggaran kegiatan pengguna anggaran yang menugaskan tenaga kependidikan.

Berdasarkan hal ini, maka dapat dilihat bahwa Intensif Kinerja Wajib (IKW) dan Intensif Kelebihan Kinerja (IKK) sebagai dasar intensif untuk remunerasi bagi tenaga kependidikan didasarkan pada persetujuan pimpinan. Terkait hal ini, maka dapat dilihat bahwa gaya kepemimpinan transformational dapat diperlihatkan di Sekolah Vokasi Universitas Diponegoro.

\section{KESIMPULAN}

Gaya kepemimpinan transformasional di Sekolah Vokasi Universitas Diponegoro diarahkan sesuai dengan visi. Pemimpin Sekolah Vokasi memiliki peran yang sangat signifikan dalam meningkatkan kualitas pelayanan. Pemimpin Sekolah Vokasi juga memainkan peranan yang sangat kritis, yaitu melalui strategi peningkatan kuantitas tenaga kependidikan, peningkatan kualitas tenaga kependidikan, dan pengembangan sistem penilaian kinerja.

\section{UCAPAN TERIMA KASIH}

Terima kasih kepada segenap informan, segenap tenaga kependidikan di Sekolah Vokasi Universitas Diponegoro beserta jajarannya. Tidak lupa penulis mengucapkan terima kasih kepada jajaran pimpinan Sekolah Vokasi Universitas Diponegoro yang telah memfasilitasi keberlangsungan riset ini.

\section{DAFTAR PUSTAKA}

Bass, B. M. (1985). Leadership and performance beyond expectations. New York: Free Press.

Gibson, J. L., Ivancevich, J. M., \& Donnelly, J. H. (1997). Organisasi dan manajemen: Perilaku, struktur, proses. Jakarta: Erlangga.

Tjiptono, F. (2014). Manajemen Jasa. Yogyakarta: Penerbit Andi.

Handoko, H., \& Tjiptono, F. (1996). Kepemimpinan transformasional dan pemberdayaan. Journal of Indonesian Economy and Business, 11(1), 23-33.

Hartanto, F. M. (1991). Peran kepemimpinan transformasional dalam upaya peningkatan produktivitas tenaga kerja di Indonesia. Jakarta : Departemen Tenaga Kerja.

Hedwig, R., \& Polla, G. (2006). Model sistem penjaminan mutu dan proses penerapannya di perguruan tinggi. Yogyakarta: Graha IImu.

Historika, N. (2012). Pengaruh gaya kepemimpinan dan motivasi kerja terhadap kinerja pegawai pada Dinas Perhubungan Provinsi Kepulauan Riau (Tesis magister). Jakarta: Program Administrasi Publik Universitas Terbuka.

Hughes, R. L., Ginnett, R. L., \& Curphy, G. J. (1993). Leadership: enhanching the lessons of experience. Boston: Irwin.

Kumaran, M. (2012). Leadership in libraries: A focus on etnic minority librarians. Oxford: Chandos Publishing.

Lukman. (2000). Analisa Pelayanan dan Kenyamanan Fasilitas Kendaraan Terhadap Kepuasan Tamu BP Batam. Batam : STT Ibnu Sina.

Mangkunegara, A. A. A. P. (2011). Manajemen sumber daya manusia perusahaan. Bandung: Remaja 
Moenir, H. A. S. (1997). Manajemen pelayanan umum di Indonesia. Jakarta: Bumi Aksara.

Siagian, S. P. (2012). Teori kepemimpinan dan sifat kepemimpinan. Jakarta: Gramedia.

Sinambela, L. P. (2006). Reformasi pelayanan publik teori, kebijakan, dan implementasi. Jakarta: PT Bumi Aksara.

Sugiyanti, U. (2012). Gaya kepemimpinan penanggung jawab perpustakaan dalam mendukung pengembangan kualitas pelayanan perpustakaan (Tesis magister). Yogyakarta: Sekolah Pasca Sarjana UGM.

Sutrisno, E. (2013). Manajemen sumber daya manusia. Jakarta: Kencana Prenada Media Group.

Reeder, L. A. (2014). The impact of leadership styles on libraries, Ph.D Dissertation. United States: Capella University.

Zeithaml, V. A., \& Bitner, M. J. (2000). Services marketing. Boston: Irwin McGraw-Hill. 